\title{
T Cell Epitope Peptide Therapy for Allergic Diseases
}

\author{
Robyn E. O'Hehir ${ }^{1,2}$ • Sara R. Prickett ${ }^{1}$ - Jennifer M. Rolland ${ }^{1,2}$ \\ Published online: 14 January 2016 \\ (C) The Author(s) 2016. This article is published with open access at Springerlink.com
}

\begin{abstract}
Careful selection of dominant T cell epitope peptides of major allergens that display degeneracy for binding to a wide array of MHC class II molecules allows induction of clinical and immunological tolerance to allergen in a refined treatment strategy. From the original concept of peptideinduced $\mathrm{T}$ cell anergy arising from in vitro studies, proof-ofconcept murine models and flourishing human trials followed. Current randomized, double-blind, placebo-controlled clinical trials of mixtures of $\mathrm{T}$ cell-reactive short allergen peptides or long contiguous overlapping peptides are encouraging with intradermal administration into non-inflamed skin a preferred delivery. Definitive immunological mechanisms are yet to be resolved but specific anergy, Th2 cell deletion, immune deviation, and Treg induction seem implicated. Significant efficacy, particularly with short treatment courses, in a range of aeroallergen therapies (cat, house dust mite, grass pollen) with inconsequential non-systemic adverse events likely heralds a new class of therapeutic for allergy, Synthetic Peptide Immuno-Regulatory Epitopes (SPIRE).
\end{abstract}

This article is part of the Topical Collection on Allergens

Robyn E. O'Hehir

r.ohehir@alfred.org.au

Sara R. Prickett

sara.prickett@monash.edu

Jennifer M. Rolland

jennifer.rolland@monash.edu

1 Department of Allergy, Immunology and Respiratory Medicine, Alfred Hospital and Central Clinical School, Monash University, Commercial Road, Melbourne, Victoria 3004, Australia

2 Department of Immunology, Monash University, Melbourne, Victoria, Australia
Keywords Tcellepitope $\cdot$ Peptide $\cdot$ SPIRE $\cdot$ Synthetic peptide immuno-regulatory epitopes $\cdot$ Allergy $\cdot$ Immunotherapy

\section{Introduction}

In 1911, Noon pioneered allergen immunotherapy (AIT) for treatment of grass pollen allergy [1]. The administration of allergen extracts using various regimens and routes is now established therapeutic practice in the management of allergic diseases, and currently the only therapy proven to modify the natural course of an allergic disease. However, treatment with whole allergen extracts is contraindicated in patients with unstable asthma and food allergies due to the risk of severe IgEmediated adverse events including anaphylaxis or even death [2-4]. These risks, together with the typically prolonged and frequent dosing regimens, command poor adherence in real life situations [5] and less than desirable availability of specific allergy treatments for the burgeoning allergy epidemic [6].

The pivotal role of the $\mathrm{CD}^{+} \mathrm{T}$ cell in driving immune responsiveness to allergen, together with distinct differences between $\mathrm{T}$ cell and $\mathrm{B}$ cell epitopes, facilitates development of refined therapeutics for redirecting the cellular immune response towards peripheral tolerance $[7,8 \bullet \bullet]$. Allergen T cell epitopes are typically short, without conformational structure. They fail to cross-link cell-bound IgE or activate inflammatory mast cells and basophils. In contrast, allergen B cell epitopes are usually conformational although linear epitopes are described. On native allergen molecules, B cell epitopes can bind and cross-link specific IgE on effector cells to trigger degranulation with inflammatory mediator release and synthesis eliciting the well-recognized features of allergy. Carefully selected dominant $\mathrm{T}$ cell epitope peptides of major clinically relevant allergens that display degeneracy for binding to a wide array of MHC class II molecules can safely induce 
clinical and immunological tolerance in a breakthrough new class of allergy treatment, recently termed Synthetic Peptide Immuno-Regulatory Epitopes (SPIRE) [8••, 9]. Evolution from the idea of allergen $T$ cell epitope-based peptide anergy [10], through proof-of-concept murine experimental models [11-13], progressed to human clinical translation [14, 15]. In recent years, there have been randomized, double-blind, placebo-controlled clinical trials of two types of $\mathrm{T}$ cell epitope-based therapeutics for allergy: short $\mathrm{T}$ cell epitope peptide mixtures and longer Contiguous Overlapping Peptides (COPs) [9, 16•]. Significant efficacy has been achieved in cat, house dust mite (HDM), and pollen allergy with short treatment courses and inconsequential non-systemic adverse events $[17,18 \bullet \bullet, 19]$. Underlying immunological mechanisms are yet to be clarified but likely include similar changes in allergen-specific $\mathrm{T}$ cell responses to those seen in conventional AIT $\left[8 \bullet \bullet, 20 \bullet \bullet\right.$. Whether induction of blocking $\operatorname{IgG}_{4}$ antibodies is required for efficacy of peptide immunotherapy is not so clear and may only be seen using longer peptides such as COPs or on re-exposure to native allergen [16•]. Promisingly, $\mathrm{T}$ cell epitope peptide therapies suggest efficacy with enhanced safety, allowing wider uptake across a range of allergic conditions.

The focus of this review is the rationale, design and utilization of $\mathrm{T}$ cell epitope-based peptides for specific treatment of allergic diseases. Selected peptides comprise immunodominant $\mathrm{T}$ cell epitopes but not IgE-binding epitopes and have minimal stimulatory potential for inflammatory cells. Their presentation is in a form that induces longlasting allergen-specific $\mathrm{T}$ cell non-responsiveness after only a short course of treatment. Recent highly encouraging clinical trials of this new class of allergy therapy and associated data on immunological mechanisms are discussed.

\section{The Rationale for T Cell Epitope Peptide Therapy for Allergic Diseases}

T cell epitope peptide therapy harnesses the established immunological dogma that dominant Tcell epitope peptides can induce anergy of specific Tcells if delivered in a way that fails to activate the T cell [21]. Induction of specific anergy utilizes the functional cytokine plasticity of Th cells to downregulate aberrant effector $\mathrm{T}$ cell responses while providing the cytokine milieu and impetus for naive $\mathrm{T}$ cells to establish protective responses [22, 23]. Additionally, the pattern of conserved $\mathrm{T}$ cell epitope repertoires observed in HDM-allergic individuals during longitudinal screening over 2 years supports this approach in contrast to the more changeable $\mathrm{T}$ cell specificities observed in longitudinal screening in autoimmune disease $[24,25]$. Human $T$ cell receptor repertoire analysis identified TCR-V $\alpha$ and TCR-V $\beta$ gene segment usage bias, together with in vivo clonal dominance by long-lived HDM-specific
T cell clones [26]. Similar in vivo longevity of venom-specific T cell clones was reported [27]. Most importantly, functional plasticity of T cells derived from the same clonal origin allows switching from dominant IL-4 to IL-10 or IFN- $\gamma$ production during anergy induction in vitro or AIT [27-29]. Another study demonstrated preferential loss (deletion) of pathogenic Th2 T cells specific for dominant allergen epitopes following successful pollen immunotherapy using fluorochromeconjugated HLA class II-peptide tetramers to quantify these T cells directly ex vivo [30••]. These features support the view that induction of specific anergy or selective elimination of dominant clonal populations of pathogenic allergen-specific $\mathrm{T}$ cells would be of therapeutic benefit in the treatment of allergic diseases.

\section{Design of T Cell Epitope Peptide Therapies for Allergic Diseases}

\section{T Cell Epitope Mapping of Major Allergens}

T cell epitope peptide therapies rely on the identification of immunodominant $\mathrm{CD}^{+}$T cell epitopes within major, clinically relevant allergens. Molecular cloning, characterization and sequencing of allergens allow the synthesis of nested sets of overlapping peptides covering the full allergen sequence. Mapping of $\mathrm{T}$ cell epitopes can then be performed using peripheral blood mononuclear cells (PBMC) from individuals with the specific allergy of interest, either directly ex vivo, or after enrichment for allergen-specificity as $\mathrm{T}$ cell lines (oligoclonal populations) or T cell clones (monoclonal populations). The most critical peptides are identified by a range of immunological assays utilising sophisticated and/or highthroughput methodologies. These include flow cytometry using dyes such as carboxyfluorescein diacetate succinimidyl ester (CFSE) to detect proliferating cells by decreased intensity of staining [31, 32], cytokine capture [33], and fluorochrome-conjugated HLA class II-peptide tetramers [27, 34]. CFSE-based approaches are sensitive for detection of peptide-responsive T cells, particularly when combined with other activation markers such as CD25 (our unpublished observation), but bystander proliferation may reduce specificity [35•]. ELISPOT-based approaches can be used for highthroughput screening of PBMC for T cell epitope peptide recognition [33, 36, 37]. Identified T cell epitopes are then validated by screening large patient population cohorts and using rigorous assay design and appropriate statistical methods (e.g., [34]).

HLA-peptide tetrameric complexes are sensitive and specific analytes for identification and characterization of allergen-specific T cells directly ex vivo, but tetramer synthesis is expensive and many HLA class II molecules are not easily isolated for use in tetramers, limiting the HLA- 
coverage obtainable [27, 34]. Unlike CFSE-approaches, tetramer-based methodologies may lack sensitivity despite high specificity [35•]. Alternatively, in silico algorithms consider thousands of known epitope sequences to predict $\mathrm{CD}^{+}$ $\mathrm{T}$ cell epitopes by detecting theoretical HLA class II binding motifs within protein sequences [38]. While algorithms provide preliminary guidance cost-effectively, comprehensiveness is limited and HLA-binding motif predictions require validation in functional peripheral blood $\mathrm{T}$ cell assays $[35 \cdot, 39]$.

Most frequently, for identification of all potential $\mathrm{T}$ cell epitopes, allergen-specific $\mathrm{T}$ cell lines and clones from large patient cohorts are screened for reactivity against overlapping synthetic peptides spanning the entire sequence of the allergen molecule, each usually 15 to 20 amino acids long with overlaps from 5 amino acids upwards. Core epitopes within T cellreactive peptides are mapped subsequently using peptide sets truncated from the $\mathrm{N}$ - and $\mathrm{C}$-termini, typically revealing eight or nine residue core epitopes for $\mathrm{CD} 4^{+} \mathrm{T}$ cells. Optimal $\mathrm{T}$ cell stimulation often requires longer sequences including flanking residues to stabilize the HLA-peptide-TCR complex and improve expression of peptide on the antigen presenting cell surface [40-42]. Consistent with naturally processed peptides eluted from HLA class II molecules, candidate peptides for inclusion in short allergen peptide therapy range from 12-20 residues $[43,44]$.

A catalogue of allergen T cell-reactive sites mapped to date is available from The Immune Epitope Database (IEDB) [45-47]. Meta-analysis identified 1406 allergen-derived $\mathrm{CD}^{+} \mathrm{T}$ cell epitopes derived from human $\mathrm{T}$ cell reactivity [48]. Despite large numbers, it is estimated that this represents $<17 \%$ of all allergens in the International Union of Immunological Societies (IUIS) allergen database [49]. T cell epitopes are found scattered throughout an allergen sequence, but consideration of collective properties of the epitopes allows ranking according to dominance to optimize peptide candidates for therapy [38]. Such properties include donor and T cell line/clone responder frequency, patterns of reactivity, reproducibility of T cell response and, importantly, ability to induce a response in patient PBMC in large patient cohorts. Identification of the most immunodominant $\mathrm{T}$ cell epitopes is important, recognizing another important immunological dogma that the stronger the immunogen the stronger the tolerogen [50]. With neighboring or overlapping epitopes, a single peptide containing the two epitopes may allow targeting of both $\mathrm{T}$ cell specificities while minimising final peptide length and number. However, validation of $\mathrm{T}$ cell recognition of both epitopes in the consolidated peptide is required, and in our experience, not always obtained, requiring retention of individual $\mathrm{T}$ cell epitope peptides. Cross-reactive $\mathrm{T}$ cell epitopes are present in some closely related allergens, e.g. group 1 grass pollen allergens [51-53], which aids broader population coverage in different regions.
For optimal production, modification of some peptides may aid solubility and stability, for example, modification of terminal residues and replacement of cysteine residues with inert alanine or non-reactive serine to prevent aggregation (e.g. [32]). Testing T cell reactivity of any modified peptide is necessary to confirm retention of T cell stimulatory capacity. As a safety index, all candidate $T$ cell epitope peptides need testing singly and in combination to exclude potential engagement and cross-linking of inflammatory cell-bound IgE. The flow cytometric basophil activation test or the histamine release test are increasingly utilized as convenient and validated read-outs of clinically relevant, functional IgE reactivity [54-57].

\section{MHC Class II Restriction Specificity}

The ability of T cell epitope peptide candidates for therapy to show widespread degeneracy of binding to a range of MHC class II molecules is important when targeting genetically diverse patient populations. Human $\mathrm{CD}^{+} \mathrm{T}$ cells recognize allergen epitopes in the context of particular HLA class II molecules encoded by one of three highly polymorphic loci, HLA-DR, HLA-DP, or HLA-DQ. HLA-binding T cell epitope prediction algorithms are popular but with variable correlation when compared with direct functional assays. Early algorithms were limited to HLA-DR binding motifs, but now extend to HLA-DQ and -DP predictions [38]. Experimental validation of predicted epitopes utilizes isolated HLA molecules and/or transfected L cells or EBV-transformed B cell lines homozygous for defined HLA alleles [8••, 58]. HLA-peptide binding assays help inform clinical relevance in addition to levels of avidity and/or affinity $[40,58,59]$.

However, to identify the full repertoire of functional HLApeptide complexes, functional read-outs of $\mathrm{T}$ cell proliferation or cytokine production with the particular HLA-peptide complex are needed. Preliminary screening of HLA-restriction specificity of $\mathrm{T}$ cell epitope recognition is achieved by using blocking monoclonal antibodies specific for HLA-DR, HLADP or HLA-DQ [8・•, 32]. HLA-genotyping of the antigen presenting cells can then inform restriction to specific HLAsubtype(s). Tetramers provide a more sophisticated method for screening in samples such as blood analyzed directly ex vivo [34] but, problematically, screens utilizing tetramers or homozygous cell lines need HLA-matched $\mathrm{CD}^{+} \mathrm{T}$ cells/ patients [60] and as discussed above, the available range of testable HLA tetramers is limited.

It is helpful that allergen $T$ cell epitopes frequently display extensive HLA-binding degeneracy while allergen-specific $\mathrm{CD} 4^{+} \mathrm{T}$ cells may recognize a particular epitope in the context of multiple HLA class II molecules [30••, 32, 33, 37, 38, 61-63]. Nominal antigens are most commonly presented on HLA-DR molecules, but allergen T cell epitopes are also presented on HLA-DQ and HLA-DP molecules (reviewed in 
[8••]). HLA-DQ and HLA-DP subtypes are often conserved more broadly across populations than HLA-DR molecules, for example HLA-DP*0401 and/or 0402 alleles are expressed in $\sim 50 \%$ of the Caucasian population [64].

\section{Learning from Experimental Models of Allergen $T$ Cell Epitope Peptide Immune Modulation}

In the early 1990s, O'Hehir and colleagues demonstrated that overnight incubation of cloned human $\mathrm{T}$ cells reactive with Der p 1 (major HDM allergen) with a supraoptimal concentration of their dominant $\mathrm{T}$ cell epitope peptide could induce specific non-responsiveness to that peptide [65]. The induction phase of anergy in this allergy model was associated with transient release of $\mathrm{Th} 2$ cytokines (notably the bronchoconstrictor IL-4) as though by hyper-excitation followed by anergy $[8 \bullet \bullet, 28,29]$. Established anergy was accompanied by decreased IL-4 and IL-5 synthesis but maintained IFN- $\gamma$ and IL-10 production $[28,65]$. Defective TCR signalling was demonstrated by abrogated activity of $\mathrm{p} 56^{\mathrm{lck}}$ and ZAP-70 tyrosine kinases in a bee venom allergen (PLA2)specific $\mathrm{CD}^{+} \mathrm{T}$ cell model [66].

Proof-of-concept for clinical translation was established initially using murine models of HDM and cat allergy [11, 12]. Importantly, these studies showed that delivering supraoptimal concentrations of a single dominant $\mathrm{T}$ cell epitope peptide in vivo not only induced specific nonresponsiveness to subsequent challenge with that peptide, but also to whole allergen extract, known as linked suppression. Such linked epitope suppression confirmed in vivo applicability of allergen T cell epitope peptides to treat allergic disease. Subsequently, the robustness of this approach was validated in other allergen models (see review [8••]). Using HLA-DR1 tetramer technology in a murine cat allergy model, Campbell et al. identified Fel d $1 \mathrm{~T}$ cell epitope peptideinduced linked epitope suppression associated with IL- $10^{+} \mathrm{T}$ cells [67]. In a murine ovalbumin TCR transgenic model, Mackenzie et al. adoptively transferred Th2-polarized cells to show preferential effects of peptide immunotherapy on cytokine secretion by $\mathrm{CD}^{2} \mathrm{~L}^{\text {lo }}$ cells (effector and effector memory $\mathrm{T}$ cells) rather than $\mathrm{CD} 62 \mathrm{~L}^{\text {hi }} \mathrm{Th} 2$ cells (central memory $\mathrm{T}$ cells) in downregulation of airway inflammation [68].

\section{Clinical Translation of T Cell Epitope Peptide Therapy for Allergy}

\section{Learning from Early Trials of Allergen Peptides in Bee Venom and Cat Allergy}

Pioneering in vivo studies in bee venom allergy confirmed that immunodominant $\mathrm{T}$ cell epitope peptides administered by subcutaneous injection induced clinical tolerance without severe adverse reactions [15]. However, these studies did not progress due to the unpredictable natural history of reactions to bee venom.

Pilot studies in cat allergy showed variable efficacy, but large protein determinants from Fel d 1 were trialled in these early studies rather than minimal epitopes $[14,69]$. A doubleblind placebo-controlled trial in 95 cat-allergic subjects comprising 4 subcutaneous doses of a Fel d 1 peptide mix (Allervax ${ }^{\circledR} \mathrm{CAT}$ ) or placebo showed clinical benefit of the peptide treatment after 6 weeks [14]. However, a range of adverse events was noted (nasal congestion, flushing, pruritus, chest tightness from minutes to hours after peptide delivery). Late asthmatic responses were triggered in some trial subjects with or without known asthma, and these were shown to be due to cytokines from peptide-stimulated T cells [70, 71]. It is tempting to speculate that the observed bronchospasm was due to the initial $\mathrm{T}$ cell activation and cytokine flare (particularly bronchoconstrictor IL-4) reported early in the induction phase of allergen peptide-induced anergy in vitro $[28,29]$. Repeated delivery and dosage adjustment attenuated the late reaction without losing efficacy. Nevertheless, these early studies with higher concentrations of longer peptides administered subcutaneously were disappointing in failing to achieve sustained clinical efficacy $[71,72]$.

\section{Synthetic Peptide Immuno-Regulatory Epitope Therapy: a New Class of Anti-allergy Therapeutic}

\section{Short Allergen T Cell Epitope Peptides}

Innovative research lead by Larché and Kay in the late 1990s and early 2000s evolved into second generation T cell epitopebased allergen peptides [70, 73]. Typically, these allergy therapeutic candidates are now mixtures of short peptides administered intradermally $(\leq 12 \mathrm{nmol} ; \sim 75 \mu \mathrm{g}$ vs $750 \mu \mathrm{g})$ into noninflamed skin $[9,18 \bullet \bullet, 56,73-76]$. While earlier studies utilized the subcutaneous route for peptide administration, a subsequent study directly comparing intradermal with subcutaneous cat peptide delivery, showed that the intradermal route had superior immunological activity as well as tolerability [56]. The first of the new-generation peptide treatment to be trialled, Cat-PAD (Circassia Ltd; Oxford, UK), comprised of 7 T cell epitope-based peptides (13-17 amino acids) from Fel d las a lyophilisate reconstituted in water for intradermal administration. Recent trials have used a painless, needle-free transdermal delivery for four to eight treatments at 2-4-week intervals with recording of Total Rhino-conjunctivitis Symptom Score and challenge testing in an Environmental Exposure Chamber $[18 \bullet \bullet, 77]$. By using short T cell epitope-based peptides, IgE cross-linking and inflammatory cell activation was avoided, and careful dose adjustments prevented the late asthmatic responses seen earlier with longer peptides. A phase IIb clinical 
field trial indicated sustained clinical efficacy out to 2 years after the initial course of Cat-PAD [78••]. As expected in a clinical trial of an allergy therapy $[79,80]$, substantial placebo effects were seen initially but were not sustained longer term. Trials of short peptide therapies exploring optimal regimens in HDM [17, 81], grass pollen [82], and ragweed pollen allergy [83] are ongoing with encouraging early findings.

\section{Contiguous Overlapping Peptides}

In parallel, a second approach utilising longer T cell epitopebased allergen peptides, termed contiguous overlapping peptides (COPs), is under active investigation and early phase clinical trials $[16 \bullet, 84,85]$. In this strategy, all possible T cell epitopes of the target allergen (birch pollen being the prototype) are included in a small set of long synthetic peptides but conformational IgE epitopes are disrupted. Phase 1/IIa clinical trials in bee venom and birch pollen allergy failed to invoke early IgE-mediated reactions and demonstrated increased specific $\mathrm{IgG}_{4}$ antibodies as observed with conventional AIT. A regimen tested in subjects with birch pollen allergy, comprising five injections in 2 months, resulted in improved nasal provocation scores. As seen in the early cat peptide trials, higher concentrations of COPs also invoked late asthmatic responses that were absent with lower peptide concentrations [16•]. It is again tempting to suggest that a surge of IL-4 release during the induction phase of anergy could explain the bronchoconstriction as a transient effect. While encouraging, further trial results for COPs are needed for convincing proof of efficacy.

\section{Analysis of Mechanisms of Action}

As clinical translation of $\mathrm{T}$ cell epitope peptide therapy for allergy progresses, the underlying immunological mechanisms must be fully elucidated $[20 \bullet \bullet, 86]$. With increasing data, distinct differences are evident from conventional AIT $[87,88]$. As seen in effective AIT with whole allergen, decreased $\mathrm{T}$ cell proliferative and cytokine response to allergen appear to follow allergen peptide immunotherapy (e.g., [72, 76]), but the precise mechanism is elusive to date. Some hallmarks of anergy are evident from the pilot bee venom study, in which decreased PLA2-specific T cell proliferation and decreased IL-2, IL-4, IL-5, IL-13, and IFN- $\gamma$ production could be reversed by IL-2 and IL-15 [15]. However, in these early experiments, the polyclonal cultures and limited phenotyping precluded delineation of re-activated anergized $\mathrm{T}$ cells and activated naive $\mathrm{T}$ cells or even Treg. A role for deletion of allergen-specific $\mathrm{T}$ cells is also feasible from the murine models. In a recent study of conventional subcutaneous AIT for grass pollen allergy, HLA class II tetramers were used to quantify allergen-specific clonal $\mathrm{T}$ cell populations ex vivo
[30••]. Findings were consistent with preferential loss of clonal Th2-type $\mathrm{T}$ cells specific for dominant epitopes of major grass pollen allergens over $\mathrm{T}$ cells specific for less-dominant epitopes with a Th-1 or Tr1-phenotype. However, tetrameric approaches rely on TCR detection on the cell surface which may be confounded by down-regulation of TCR expression on anergic T cells. In this study, the pathogenic Th2 cells also lacked CD27 expression as an additional marker suggesting selective loss of these cells.

Increased synthesis of IL-10 and induction of Treg are consistently reported as mechanisms of effective conventional AIT. Comparably, similar findings were reported in the early bee venom and cat allergen peptide studies [72, 89]. Specifically, the studies of cat allergen peptide treatment demonstrated a requirement for IL-10 in order to induce suppression of allergen-specific responses and invoke linked epitope suppression [67], and also to see an allergen-specific $\mathrm{CD}^{+}$Treg population [90]. Skin allergen challenge biopsies revealed enhanced $\mathrm{CD} 4^{+} \mathrm{IFN}-\gamma^{+}$and $\mathrm{CD} 25^{+}$cells following peptide treatment consistent with immune deviation and Tregs [91]. However, the overlap between surface markers on effector cells and Tregs, particularly when activated, makes interpretation of clinical biopsies difficult [92].

Peptide lengths selected for $\mathrm{T}$ cell epitope-based therapy may determine whether specific $\mathrm{IgG}_{4}$ blocking antibody is generated. Peptides based on individual minimal T cell epitope sequences are short and screened for lack of $\operatorname{IgE}$ binding and inflammatory cell activating potential, so would seem less likely to be immunogenic. Nevertheless, boosting by exposure to whole allergen in a modified cytokine milieu might conceivably drive $\operatorname{IgA}$ or $\operatorname{IgG}_{4}$ antibody production. The initial pilot bee venom study detected no antibody changes but, following subcutaneous rechallenge with whole allergen, an increase in specific $\mathrm{IgG}_{4}$ could be detected [15]. In a study by Tarzi et al., only a negligible and transient elevation in specific $\mathrm{IgG}_{4}$ was seen [89]. In contrast, repeated administration of COPs for birch pollen allergy resulted in a marked increase in Bet v 1-specific $\mathrm{IgG}_{4}$ levels over baseline and compared with placebo [16•]. As the data from current and future clinical trials accumulate, there will be greater appreciation of $\mathrm{IgG}_{4}$ changes as mechanistic or an epiphenomenon. Blocking antibodies are demonstrably important in conventional AIT but seem less relevant for sustained unresponsiveness [20••, 93].

\section{Conclusions}

A new class of specific $\mathrm{T}$ cell epitope peptide therapy for allergic diseases, perhaps to be known as SPIRE, is growing in momentum with encouraging data in clinical trials across a range of allergens. Immunodominant $\mathrm{T}$ cell epitope-based allergen peptides seem able to induce sustained clinical tolerance although the underlying immunological mechanisms are 
yet to be clarified. Core epitope mapping to inform peptide selection identifies the critical amino acid sequences that can invoke desired clinical tolerance without undesirable cellbound IgE cross-linking and inflammatory sequelae. Promiscuity of binding of these dominant allergen peptides to a wide range of HLA class II molecules offers widespread clinical utility without need for individual patient endotyping. In particular, emerging evidence of sustained efficacy in the presence of ongoing exposure to ensure retained memory after relatively short treatment courses without adverse events gives hope that allergology is poised for a therapeutic revolution. The observed pattern of efficacy suggests an important role for anergy as a key mechanism for this class of therapy. Expansion of this treatment approach to encompass specific therapies for food allergies, particularly peanut allergy, is advanced and early phase trials are awaited with interest. Additionally, research into possible applicability for mould allergy and cockroach allergy seems worthy of concentrated effort. After more than 100 years since specific immunotherapy was introduced as a treatment to modify the natural course of allergic disease, it is gratifying that harnessing fundamental immunological principles may allow more widespread modulation of the aberrant immune response to allergens that causes such a major socio-economic health burden globally.

\section{Compliance with Ethical Standards}

Conflict of Interest Drs. O'Hehir, Prickett, and Rolland declare no conflicts of interest.

Human and Animal Rights and Informed Consent This article does not contain any studies with human or animal subjects performed by any of the authors.

Open Access This article is distributed under the terms of the Creative Commons Attribution 4.0 International License (http:// creativecommons.org/licenses/by/4.0/), which permits unrestricted use, distribution, and reproduction in any medium, provided you give appropriate credit to the original author(s) and the source, provide a link to the Creative Commons license, and indicate if changes were made.

\section{References}

Papers of particular interest, published recently, have been highlighted as:

- Of importance

•- Of major importance

1. Noon L. Prophylactic inoculation against hay fever. Lancet. 1911;177(4580):1555-626.

2. Burks AW, Calderon MA, Casale T, Cox L, Demoly P, Jutel M, et al. Update on allergy immunotherapy: American Academy of Allergy, Asthma \& Immunology/European Academy of Allergy and Clinical Immunology/PRACTALL consensus report. J Allergy Clin Immunol. 2013;131(5):1288-96 e3.
3. Canonica GW, Bousquet J, Casale T, Lockey RF, Baena-Cagnani CE, Pawankar R, et al. Sub-lingual immunotherapy: World Allergy Organization Position Paper 2009. Allergy. 2009;64 Suppl 91:159.

4. Compalati E, Braido F, Canonica GW. An update on allergen immunotherapy and asthma. Curr Opin Pulm Med. 2014;20(1):109 17.

5. Kiel MA, Roder E, Gerth van Wijk R, Al MJ, Hop WC, Rutten-van Molken MP. Real-life compliance and persistence among users of subcutaneous and sublingual allergen immunotherapy. J Allergy Clin Immunol. 2013;132(2):353-60 e2.

6. Cox L, Jacobsen L. Comparison of allergen immunotherapy practice patterns in the United States and Europe. Ann Allergy Asthma Immunol. 2009;103(6):451-9. quiz 9-61, 95.

7. Sandrini A, Rolland JM, O'Hehir RE. Current developments for improving efficacy of allergy vaccines. Expert Rev Vaccines. 2015;14:1073-87.

8.• Prickett SR, Rolland JM, O'Hehir RE. Immunoregulatory T cell epitope peptides: the new frontier in allergy therapy. Clin Exp Allergy. 2015;45(6):1015-26. Comprehensive review of strategies for designing $\mathbf{T}$ cell epitope-based peptide therapy for allergy.

9. Worm M. SPIREs: a new horizon for allergic disease treatment? Expert Rev Clin Immunol. 2015;11(11):1173-5.

10. O'Hehir RE, Hoyne GF, Thomas WR, Lamb JR. House dust mite allergy: from T-cell epitopes to immunotherapy. Eur J Clin Invest. 1993;23(12):763-72.

11. Hoyne GF, O'Hehir RE, Wraith DC, Thomas WR, Lamb JR. Inhibition of $\mathrm{T}$ cell and antibody responses to house dust mite allergen by inhalation of the dominant $\mathrm{T}$ cell epitope in naive and sensitized mice. J Exp Med. 1993;178(5):1783-8.

12. Briner TJ, Kuo MC, Keating KM, Rogers BL, Greenstein JL. Peripheral T-cell tolerance induced in naive and primed mice by subcutaneous injection of peptides from the major cat allergen Fel d I. Proc Natl Acad Sci U S A. 1993;90(16):7608-12.

13. Bauer L, Bohle B, Jahn-Schmid B, Wiedermann U, Daser A, Renz $\mathrm{H}$, et al. Modulation of the allergic immune response in BALB/c mice by subcutaneous injection of high doses of the dominant $T$ cell epitope from the major birch pollen allergen Bet v 1. Clin Exp Immunol. 1997;107(3):536-41.

14. Norman PS, Ohman Jr JL, Long AA, Creticos PS, Gefter MA, Shaked Z, et al. Treatment of cat allergy with T-cell reactive peptides. Am J Respir Crit Care Med. 1996;154(6 Pt 1):1623-8.

15. Muller U, Akdis CA, Fricker M, Akdis M, Blesken T, Bettens F, et al. Successful immunotherapy with T-cell epitope peptides of bee venom phospholipase A2 induces specific T-cell anergy in patients allergic to bee venom. J Allergy Clin Immunol. 1998;101(6 Pt 1): $747-54$.

16. Spertini F, Perrin Y, Audran R, Pellaton C, Boudousquie C, Barbier $\mathrm{N}$, et al. Safety and immunogenicity of immunotherapy with Bet $\mathrm{v}$ 1 -derived contiguous overlapping peptides. J Allergy Clin Immunol. 2014;134(1):239-40 e13. This study provides promising evidence for efficacy of contiguous overlapping peptides (COPs) for treatment of birch pollen allergy. Nasal provocation scores were improved and Bet $\mathrm{v}$ 1-specific $\mathrm{IgG}_{4}$ levels increased without evidence for adverse IgE mediated reactions.

17. Hafner RP, Couroux P, Armstrong K, Salapatek AM, Patel D, Larche M. Four doses of Der $p$ derived synthetic peptide immuno-regulatory epitopes over 3 months results in a persistent treatment effect at 1 year on symptoms of House Dust Mite allergy. Allergy. 2014;69:31-2.

18.• Worm M, Patel D, Creticos PS. Cat peptide antigen desensitisation for treating cat allergic rhinoconjunctivitis. Expert Opin Investig Drugs. 2013;22(10):1347-57. Excellent review of development and clinical trial of $T$ cell epitope peptide-based treatment for 
cat allergy, with evidence for a well-tolerated and promising new therapeutic approach.

19. Ellis AK, Frankish CW, Armstrong K, Larche M, O'Hehir RE, Steacey LM, et al. A short course of synthetic peptide immunoregulatory epitopes derived from grass allergens leads to a reduction in grass allergy symptoms. Allergy. 2014;69:32.

20.• Larche M. Mechanisms of peptide immunotherapy in allergic airways disease. Ann Am Thorac Soc. 2014;11 Suppl 5:S292-6. Critical appraisal of experimental evidence for mechanisms of peptide immunotherapy for allergy.

21. Lamb JR, Skidmore BJ, Green N, Chiller JM, Feldmann M. Induction of tolerance in influenza virus-immune $\mathrm{T}$ lymphocyte clones with synthetic peptides of influenza hemagglutinin. J Exp Med. 1983;157(5):1434-47.

22. Murphy KM, Stockinger B. Effector T cell plasticity: flexibility in the face of changing circumstances. Nat Immunol. 2010;11(8):674 80 .

23. Zhu J, Paul WE. Heterogeneity and plasticity of T helper cells. Cell Res. 2010;20(1):4-12.

24. Verhoef A, Higgins JA, Thorpe CJ, Marsh SG, Hayball JD, Lamb $\mathrm{JR}$, et al. Clonal analysis of the atopic immune response to the group 2 allergen of Dermatophagoides spp.: identification of HLA-DR and -DQ restricted T cell epitopes. Int Immunol. 1993;5(12):1589-97.

25. Lehmann PV, Forsthuber T, Miller A, Sercarz EE. Spreading of Tcell autoimmunity to cryptic determinants of an autoantigen. Nature. 1992;358(6382):155-7.

26. Wedderburn LR, O'Hehir RE, Hewitt CR, Lamb JR, Owen MJ. In vivo clonal dominance and limited T-cell receptor usage in human CD4+ T-cell recognition of house dust mite allergens. Proc Natl Acad Sci U S A. 1993;90(17):8214-8.

27. Aslam A, Chan H, Warrell DA, Misbah S, Ogg GS. Tracking antigen-specific T-cells during clinical tolerance induction in humans. PLoS One. 2010;5(6):e11028.

28. O'Hehir RE, Lake RA, Schall TJ, Yssel H, Panagiotopoulou E, Lamb JR. Regulation of cytokine and chemokine transcription in a human TH2 type T-cell clone during the induction phase of anergy. Clin Exp Allergy. 1996;26(1):20-7.

29. Hoyne GF, Askonas BA, Hetzel C, Thomas WR, Lamb JR. Regulation of house dust mite responses by intranasally administered peptide: transient activation of $\mathrm{CD} 4+\mathrm{T}$ cells precedes the development of tolerance in vivo. Int Immunol. 1996;8(3):335-42.

30.• Wambre E, DeLong JH, James EA, Torres-Chinn N, Pfutzner W, Mobs $\mathrm{C}$, et al. Specific immunotherapy modifies allergen-specific CD4(+) T-cell responses in an epitope-dependent manner. J Allergy Clin Immunol. 2014;133(3):872-9 e7. An elegant study in timothy grass pollen allergen immunotherapy utilizing an ex vivo peptide-MHC class II tetramer approach to demonstrate preferential deletion of allergen-specific Th2 cells.

31. Mannering SI, Dromey JA, Morris JS, Thearle DJ, Jensen KP, Harrison LC. An efficient method for cloning human autoantigenspecific T cells. J Immunol Methods. 2005;298(1-2):83-92.

32. Prickett SR, Voskamp AL, Dacumos-Hill A, Symons K, Rolland JM, O'Hehir RE. Ara h 2 peptides containing dominant CD4+ Tcell epitopes: candidates for a peanut allergy therapeutic. J Allergy Clin Immunol. 2011;127(3):608-15 e1-5.

33. Oseroff C, Sidney J, Kotturi MF, Kolla R, Alam R, Broide DH, et al. Molecular determinants of $\mathrm{T}$ cell epitope recognition to the common Timothy grass allergen. J Immunol. 2010;185(2):943-55.

34. Kwok WW, Roti M, Delong JH, Tan V, Wambre E, James EA, et al. Direct ex vivo analysis of allergen-specific CD4+ T cells. J Allergy Clin Immunol. 2010;125(6):1407-9 e1.

35. Van Hemelen D, Mahler V, Fischer G, Fae I, Reichl-Leb V, Pickl W, et al. HLA class II peptide tetramers vs allergen-induced proliferation for identification of allergen-specific CD4 T cells. Allergy. 2015;70(1):49-58. Comprehensive comparison of two pivotal experimental approaches for identification and analysis of allergen-specific $T$ cells.

36. Tye-Din JA, Stewart JA, Dromey JA, Beissbarth T, van Heel DA, Tatham A, et al. Comprehensive, quantitative mapping of $\mathrm{T}$ cell epitopes in gluten in celiac disease. Sci Transl Med. 2010;2(41): 41ra51.

37. Bateman EA, Ardern-Jones MR, Ogg GS. Identification of an immunodominant region of Fel d 1 and characterization of constituent epitopes.[see comment]. Clin Exp Allergy. 2008;38(11):17608.

38. Schulten V, Oseroff C, Alam R, Broide D, Vijayanand P, Peters B, et al. The identification of potentially pathogenic and therapeutic epitopes from common human allergens. Ann Allergy Asthma Immunol. 2013;110(1):7-10.

39. Lundegaard C, Lund O, Nielsen M. Predictions versus highthroughput experiments in T-cell epitope discovery: competition or synergy? Expert Rev Vaccines. 2012;11(1):43-54.

40. Knapp B, Fischer G, Van Hemelen D, Fae I, Maillere B, Ebner C, et al. Association of HLA-DR1 with the allergic response to the major mugwort pollen allergen: molecular background. BMC Immunol. 2012;13:43.

41. Knapp B, Omasits U, Bohle B, Maillere B, Ebner C, Schreiner W, et al. 3-Layer-based analysis of peptide-MHC interaction: in silico prediction, peptide binding affinity and $\mathrm{T}$ cell activation in a relevant allergen-specific model. Mol Immunol. 2009;46(8-9):183944.

42. Maillere B, Mourier G, Herve M, Menez A. Fine chemical modifications at $\mathrm{N}$ - and $\mathrm{C}$-termini enhance peptide presentation to $\mathrm{T}$ cells by increasing the lifespan of both free and MHC-complexed peptides. Mol Immunol. 1995;32(17-18):1377-85.

43. Mutschlechner S, Egger M, Briza P, Wallner M, Lackner P, Karle A, et al. Naturally processed T cell-activating peptides of the major birch pollen allergen. J Allergy Clin Immunol. 2010;125(3):711-8 8 e1-8 e2.

44. Rudensky A, Preston-Hurlburt P, Hong SC, Barlow A, Janeway Jr CA. Sequence analysis of peptides bound to MHC class II molecules. Nature. 1991;353(6345):622-7.

45. Immune Epitope Database and Analysis Resource [Internet]. [cited November 2015]. Available from: http://www.immuneepitope.org.

46. Salimi N, Fleri W, Peters B, Sette A. The immune epitope database: a historical retrospective of the first decade. Immunology. 2012;137(2):117-23.

47. Vita R, Zarebski L, Greenbaum JA, Emami H, Hoof I, Salimi N, et al. The immune epitope database 2.0. Nucleic Acids Res. 2010;38(Database issue):D854-62.

48. Vaughan K, Greenbaum J, Kim Y, Vita R, Chung J, Peters B, et al. Towards defining molecular determinants recognized by adaptive immunity in allergic disease: an inventory of the available data. J Allergy (Cairo). 2010;2010:628026.

49. Allergen Nomenclature, International Union of Immunological Societies [Internet]. [cited 2015]. Available from: http://www. allergen.org.

50. Gammon G, Sercarz E. How some T cells escape tolerance induction. Nature. 1989;342(6246):183-5.

51. Etto T, de Boer C, Prickett S, Gardner LM, Voskamp A, Davies JM, et al. Unique and cross-reactive T cell epitope peptides of the major Bahia grass pollen allergen, Pas $\mathrm{n} 1$. Int Arch Allergy Immunol. 2012;159(4):355-66.

52. Jahn-Schmid B, Radakovics A, Luttkopf D, Scheurer S, Vieths S, Ebner C, et al. Bet v 1142-156 is the dominant T-cell epitope of the major birch pollen allergen and important for cross-reactivity with Bet v 1-related food allergens. J Allergy Clin Immunol. 2005;116(1):213-9.

53. Sone T, Dairiki K, Morikubo K, Shimizu K, Tsunoo H, Mori T, et al. Identification of human $\mathrm{T}$ cell epitopes in Japanese cypress pollen allergen, Cha o 1, elucidates the intrinsic mechanism of cross- 
allergenicity between Cha o 1 and Cry j 1, the major allergen of Japanese cedar pollen, at the T cell level. Clin Exp Allergy. 2005;35(5):664-71.

54. Drew AC, Eusebius NP, Kenins L, de Silva HD, Suphioglu C, Rolland JM, et al. Hypoallergenic variants of the major latex allergen Hev b 6.01 retaining human $\mathrm{T}$ lymphocyte reactivity. J Immunol. 2004;173(9):5872-9.

55. Prickett SR, Voskamp AL, Phan T, Dacumos-Hill A, Mannering SI, Rolland JM, et al. Ara h 1 CD4+ T-cell epitope-based peptides: candidates for a peanut allergy therapeutic. Clin Exp Allergy. 2013;43(6):684-97.

56. Worm M, Lee HH, Kleine-Tebbe J, Hafner RP, Laidler P, Healey D, et al. Development and preliminary clinical evaluation of a peptide immunotherapy vaccine for cat allergy. J Allergy Clin Immunol. 2011;127(1):89-97 e1-14.

57. Santos AF, Douiri A, Becares N, Wu SY, Stephens A, Radulovic S, et al. Basophil activation test discriminates between allergy and tolerance in peanut-sensitized children. J Allergy Clin Immunol. 2014;134(3):645-52.

58. McKinney DM, Southwood S, Hinz D, Oseroff C, Arlehamn CS, Schulten V, et al. A strategy to determine HLA class II restriction broadly covering the DR, DP, and DQ allelic variants most commonly expressed in the general population. Immunogenetics. 2013;65(5):357-70.

59. ProImmune. ProImmune REVEAL ${ }^{\circledR}$ Class II Rapid Epitope Discovery System Accessed 2015. Available from: https://www. proimmune.com/ecommerce/page.php?page=reveal_class2.

60. Nepom GT. MHC class II tetramers. J Immunol. 2012;188(6): 2477-82.

61. Crack LR, Chan HW, McPherson T, Ogg GS. Identification of an immunodominant region of the major house dust mite allergen Der p 2 presented by common human leucocyte antigen alleles. Clin Exp Dermatol. 2012;37(3):266-76.

62. Friedl-Hajek R, Spangfort MD, Schou C, Breiteneder H, Yssel H, Joost van Neerven RJ. Identification of a highly promiscuous and an HLA allele-specific T-cell epitope in the birch major allergen Bet v 1: HLA restriction, epitope mapping and TCR sequence comparisons. Clin Exp Allergy. 1999;29(4):478-87.

63. DeLong JH, Simpson KH, Wambre E, James EA, Robinson D, Kwok WW. Ara h 1-reactive T cells in individuals with peanut allergy. J Allergy Clin Immunol. 2011;127(5):1211-8 e3.

64. Castelli FA, Buhot C, Sanson A, Zarour H, Pouvelle-Moratille S, Nonn C, et al. HLA-DP4, the most frequent HLA II molecule, defines a new supertype of peptide-binding specificity. J Immunol. 2002;169(12):6928-34.

65. O'Hehir RE, Yssel H, Verma S, de Vries JE, Spits H, Lamb JR. Clonal analysis of differential lymphokine production in peptide and superantigen induced T cell anergy. Int Immunol. 1991;3(8): 819-26.

66. Faith A, Akdis CA, Akdis M, Simon HU, Blaser K. Defective TCR stimulation in anergized type $2 \mathrm{~T}$ helper cells correlates with abrogated p56(lck) and ZAP-70 tyrosine kinase activities. J Immunol. 1997;159(1):53-60.

67. Campbell JD, Buckland KF, McMillan SJ, Kearley J, Oldfield WL, Stern LJ, et al. Peptide immunotherapy in allergic asthma generates IL-10-dependent immunological tolerance associated with linked epitope suppression. J Exp Med. 2009;206(7):1535-47.

68. Mackenzie KJ, Fitch PM, Leech MD, Ilchmann A, Wilson C, McFarlane AJ, et al. Combination peptide immunotherapy based on T-cell epitope mapping reduces allergen-specific $\operatorname{IgE}$ and eosinophilia in allergic airway inflammation. Immunology. 2013;138(3): 258-68.

69. Wallner BP, Gefter ML. Immunotherapy with T-cell-reactive peptides derived from allergens. Allergy. 1994;49(5):302-8.

70. Haselden BM, Kay AB, Larche M. Immunoglobulin E-independent major histocompatibility complex-restricted T cell peptide epitope- induced late asthmatic reactions. J Exp Med. 1999;189(12):188594.

71. Maguire P, Nicodemus C, Robinson D, Aaronson D, Umetsu DT The safety and efficacy of ALLERVAX CAT in cat allergic patients. Clin Immunol. 1999;93(3):222-31.

72. Simons FE, Imada M, Li Y, Watson WT, HayGlass KT. Fel d 1 peptides: effect on skin tests and cytokine synthesis in cat-allergic human subjects. Int Immunol. 1996;8(12):1937-45.

73. Oldfield WL, Larche M, Kay AB. Effect of T-cell peptides derived from Fel d 1 on allergic reactions and cytokine production in patients sensitive to cats: a randomised controlled trial. Lancet. 2002;360(9326):47-53.

74. Larche M. Peptide immunotherapy for allergic diseases. Allergy. 2007;62(3):325-31

75. Larche M. T cell epitope-based allergy vaccines. Curr Top Microbiol Immunol. 2011;352:107-19.

76. Smith TR, Alexander C, Kay AB, Larche M, Robinson DS. Cat allergen peptide immunotherapy reduces $\mathrm{CD} 4(+) \mathrm{T}$ cell responses to cat allergen but does not alter suppression by CD4(+) CD25(+) T cells: a double-blind placebo-controlled study. Allergy. 2004;59(10):1097-101.

77. Creticos PS. Advances in synthetic peptide immuno-regulatory epitopes. World Allergy Organ J. 2014;7(1):30.

78.• Couroux P, Patel D, Armstrong K, Larche M, Hafner RP. Fel d 1derived synthetic peptide immuno-regulatory epitopes show a longterm treatment effect in cat allergic subjects. Clin Exp Allergy. 2015;45(5):974-81. Demonstration of sustained clinical efficacy (cat exposure chamber challenge) out to two years after course of $\mathbf{4}$ treatments with cat allergen peptides at 4 -week intervals.

79. Narkus A, Lehnigk U, Haefner D, Klinger R, Pfaar O, Worm M. The placebo effect in allergen-specific immunotherapy trials. Clin Transl Allergy. 2013;3(1):42.

80. Durham SR. Sublingual immunotherapy: what have we learnt from the 'big trials'? Curr Opin Allergy Clin Immunol. 2008;8(6):57784

81. Larche M, Hickey P, Hebert J, Hafner R. Safety and tolerability of escalating doses of house dust mite- peptide antigen desensitization (HDM-PAD). J Allergy Clin Immunol. 2013;131(2):Ab37-Ab.

82. Ellis A, Frankish CW, Armstrong K, Larche M, Steacy L, Hafner R, et al. Persistent Treatment Effect with Grass Synthetic Peptide Immuno-Regulatory Epitopes in Grass Allergy Symptoms in an Environmental Exposure Unit Challenge after a Second Season of Natural Pollen Exposure. J Allergy Clin Immunol. 2015;135(2): Ab158-Ab.

83. Hafner R, Salapatek A, Patel D, Larche M, Laidler P. Validation of peptide immunotherapy as a new approach in the treatment of allergic rhinoconjunctivitis: The clinical benefits of treatment with Amb a 1-derived $\mathrm{T}$ cell epitopes. J Allergy Clin Immunol. 2012;129(2):AB368.

84. Pellaton C, Perrin Y, Boudousquie C, Barbier N, Wassenberg J, Corradin G, et al. Novel birch pollen specific immunotherapy formulation based on contiguous overlapping peptides. Clin Transl Allergy. 2013;3(1):17.

85. Fellrath JM, Kettner A, Dufour N, Frigerio C, Schneeberger D, Leimgruber A, et al. Allergen-specific T-cell tolerance induction with allergen-derived long synthetic peptides: results of a phase I trial. J Allergy Clin Immunol. 2003;111(4):854-61.

86. Larche M, Wraith DC. Peptide-based therapeutic vaccines for allergic and autoimmune diseases. Nat Med. 2005;11(4 Suppl):S69-76.

87. Akdis M, Akdis CA. Mechanisms of allergen-specific immunotherapy: multiple suppressor factors at work in immune tolerance to allergens. J Allergy Clin Immunol. 2014;133(3):621-31.

88. O'Hehir RE, Sandrini A, Anderson GP, Rolland JM. Sublingual allergen immunotherapy: immunological mechanisms and prospects for refined vaccine preparation. Curr Med Chem. 2007;14(21):2235-44. 
89. Tarzi M, Klunker S, Texier C, Verhoef A, Stapel SO, Akdis CA, et al. Induction of interleukin-10 and suppressor of cytokine signalling-3 gene expression following peptide immunotherapy. Clin Exp Allergy. 2006;36(4):465-74.

90. Verhoef A, Alexander C, Kay AB, Larche M. T cell epitope immunotherapy induces a CD4+ T cell population with regulatory activity. PLoS Med. 2005;2(3):e78.

91. Alexander C, Ying S, Kay AB, Larche M. Fel d 1-derived T cell peptide therapy induces recruitment of $\mathrm{CD} 4+\mathrm{CD} 25+$; CD4+ interferon-gamma $+\mathrm{T}$ helper type 1 cells to sites of allergeninduced late-phase skin reactions in cat-allergic subjects. Clin Exp Allergy. 2005;35(1):52-8.

92. Rolland JM, Gardner LM, O'Hehir RE. Functional regulatory T cells and allergen immunotherapy. Curr Opin Allergy Clin Immunol. 2010;10(6):559-66.

93. Plaut M, Rotrosen D. Tolerance induced by allergen immunotherapy. Clin Allergy Immunol. 2004;18:681-702. 